\title{
SCIENTIFIC REP RTS \\ OPEN Publisher Correction: Trapping and manipulation of nanoparticles using multifocal optical vortex metalens
}

\section{Yanbao Ma, Guanghao Rui, Bing Gu \& Yiping Cui}

Correction to: Scientific Reports https://doi.org/10.1038/s41598-017-14449-y, published online 03 November 2017

The original HTML version of this Article contained a typographical error in the publication date ' 03 November 2017 ' which was incorrectly given as '06 November 2017'. This has now been corrected in the HTML version of the Article.

(1) Open Access This article is licensed under a Creative Commons Attribution 4.0 International (c) License, which permits use, sharing, adaptation, distribution and reproduction in any medium or format, as long as you give appropriate credit to the original author(s) and the source, provide a link to the Creative Commons license, and indicate if changes were made. The images or other third party material in this article are included in the article's Creative Commons license, unless indicated otherwise in a credit line to the material. If material is not included in the article's Creative Commons license and your intended use is not permitted by statutory regulation or exceeds the permitted use, you will need to obtain permission directly from the copyright holder. To view a copy of this license, visit http://creativecommons.org/licenses/by/4.0/.

(C) The Author(s) 2018 